\title{
POLA PERSEBARAN TINGGALAN BUDAYA MEGALITIK DI LEUWISARI,
} TASIKMALAYA

The Distribution Pattern of Megalithic Cultural Remains in Leuwisari, Tasikmalaya

\author{
Sudarti Prijono \\ Balai Arkeologi Bandung \\ Jl. Raya Cinunuk K.17 Cileunyi, Bandung 40393 \\ Email: sudarti_25@yahoo.com
}

Naskah diterima: 11-05-2015; direvisi: 09-06-2015; disetujui: 28-07-2015

\begin{abstract}
Ancient society determined the location for their settlement and activity according to particular zone and pattern. The existence of these sites is predicted to had been patterned. This study aims to reveal the distribution of megalithic sites in Leuwisari, as well other aspects related to adaptation strategy. The data were collected through survey and literature study. The data were analyzed through spatial archaeology and ecology approaches. The result of this study shows that megalithic culture had been developed in this area with settlement pattern following river flow. Ancient society used natural resources to support their daily life and religious aspect.

Keywords: step pyramid, river, menhir, settlement.
\end{abstract}

\begin{abstract}
Abstrak
Masyarakat masa lampau memilih lokasi beraktivitas dan bermukim dengan mengikuti pola dan zona tertentu. Keberadaan situs-situs ini diperkirakan telah terpolakan. Penelitian ini bertujuan untuk mengungkap persebaran situs-situs budaya megalitik di wilayah Leuwisari serta aspek lain yang berkaitan dengan strategi adaptasi. Data dikumpulkan melalui survei dan studi kepustakaan. Analisis data dilakukan dengan pendekatan arkeologi ruang dan ekologi. Hasil yang diperoleh memberikan gambaran bahwa di wilayah ini pernah berkembang budaya megalitik dengan pola penempatan situs yang mengikuti aliran sungai atau sumber daya air. Masyarakat masa lalu memanfaatkan sumber daya alam untuk mendukung kehidupan yang berkaitan dengan aspek religi dan permukiman.

Kata Kunci: punden, sungai, menhir, permukiman.
\end{abstract}

\section{PENDAHULUAN}

Penelitian mengenai sisa-sisa kehidupan manusia masa lampau khususnya masyarakat budaya megalitik di Leuwisari menemukan beberapa tinggalan berupa situs dengan artefak yang menggambarkan adanya aktivitas yang berkaitan dengan religi dan permukiman. Demikian pula persebaran situs-situs arkeologi di wilayah ini menunjukkan adanya keseragaman dalam tata letaknya, yaitu berada pada geografis berupa dataran tinggi. Penelitian survei yang dilakukan di wilayah ini berhasil menemukan tinggalan budaya dalam bentuk menhir, batu datar, punden, kubur, fragmen tembikar, kerak besi, lokasi dan koordinat situs yang umumnya berada dekat dengan sumber daya alam, yaitu sumber daya air baik berupa sungai atau mata air. Keberadaan situs di suatu lokasi tertentu tidak hanya ditentukan oleh faktor alam semata, namun faktor perilaku manusia juga ikut menentukan lokasi situs sesuai dengan fungsi yang dikehendaki oleh masyarakat pendukungnya, yaitu bersifat sakral atau profan. Hal ini dapat terjadi karena adanya perilaku manusia yang berorientasi pada seperangkat aturan atau norma dalam 
suatu kebudayaan yang dianut oleh manusia secara berkesinambungan dan telah disepakati oleh masyarakat pendukungnya. Manusia masa lampau dalam menentukan dan memilih lokasi untuk beraktivitas, serta bertempat tinggal tidak akan dilakukan secara acak, melainkan penempatan situs-situs akan berpola dan mengikuti zona-zona tertentu adanya normanorma atau aturan tersebut (Siregar 2010, 1926).

Berdasarkan uraian di atas, makalah ini membahas tentang pola sebaran situssitus tinggalan budaya megalitik di wilayah Leuwisari dan hubungan antara manusia pendukung budaya megalitik wilayah Leuwisari dengan lingkungan alamnya terkait dengan pola sebaran situs tersebut. Penelitian ini bertujuan untuk mengetahui interaksi manusia pendukung budaya megalitik dengan lingkungan alamnya di wilayah Leuwisari.

Sesuai dengan tujuan tersebut, penelitian ini menggunakan pendekatan keruangan dan ekologi untuk memecahkan permasalahan penelitian. Pendekatan ini berpatokan bahwa lingkungan alam, manusia, dan budaya merupakan tiga faktor yang saling terkait dan saling mempengaruhi. Ketiga faktor tersebut dapat diterima secara lebih luas dalam dimensi ruang dan waktu. Aspek-aspek yang berkaitan dengan lingkungan meliputi bentang alam, kondisi tanah, iklim, flora, fauna, bahan mineral batuan, dan lain-lain. Gambaran lingkungan alam masa lampau diperoleh melalui pengamatan lingkungan alam saat ini dengan perkiraan bahwa kondisi alam masa lampau sama dengan kondisi alam sekarang. Berdasarkan hal tersebut, pemecahan masalah juga memakai kajian skala makro dengan mempelajari sebaran benda-benda arkeologi dan hubungan lokasional antara situs-situs dalam suatu kawasan (Mundardjito 1995, 25; Siregar 2010, 20).

Sementara itu melalui pendekatan ekologi, Peter B. Hammond menyatakan bahwa setiap sistem budaya akan cenderung dipengaruhi oleh faktor-faktor lingkungannya seperti kondisi flora, fauna, topografi, ketinggian tempat, cuaca dan sebagainya. Hammond menyebutkan juga bahwa yang dimaksud dengan prinsip ekologi adalah adaptasi terhadap lingkungan, sedangkan yang dimaksud dengan cultural ecology, yaitu menyangkut suatu proses perkembangan dalam adaptasi suatu budaya terhadap lingkungannya (Hammond 1968, 427; Prijono 2014, 49). Berdasarkan pernyataan di atas, ruang merupakan wilayah yang ditempati oleh manusia atau masyarakat untuk tinggal menetap atau sementara yang hidup dengan beradaptasi terhadap lingkungan alamnya melalui teknologi yang dikuasainya untuk memanfaatkan sumber daya alam yang ada dalam memenuhi kebutuhan hidup seharihari. Oleh karena itu, terdapat perbedaan pola penempatan situs yang sesuai dengan kondisi geografisnya sehingga ditemukan situs-situs arkeologi yang berlokasi di perbukitan, dataran rendah, tepi sungai, tepi danau, atau tepi pantai (Siregar 2010, 19). Berkaitan dengan hal tersebut, pembahasan artikel ini menggunakan situs-situs di Leuwisari yang pada umumnya berada di perbukitan sebagai bahan yang dikaji.

Hal yang utama dalam pemilihan suatu lokasi bagi pendukung budaya megalitik adalah penentuan lokasi yang berfungsi sebagai tempat pemujaan yang umumnya memiliki spesifikasi tertentu, antara lain memiliki sumber daya air dan batuan untuk bahan pembuat media megalitik, serta aksesibilitas atau kemudahan untuk mendapatkannya (Eriawati 2004, 59). Selain faktor aksesibilitas, kemudahan pengangkatan batuan dari sumbernya dan transportasi ke tempat yang ditentukan juga menjadi faktor yang tidak kalah penting.

\section{METODE}

Secara astronomis, Kecamatan Leuwisari terletak pada $108^{\circ} 05^{\prime} 52,44^{\prime \prime}$ BT sampai $108^{\circ} 04^{\prime} 20,10^{\prime \prime}$ BT dan $07^{\circ} 17^{\prime} 53,63^{\prime \prime}$ LS sampai $07^{\circ} 18^{\prime} 42,71^{\prime \prime}$ LS. Wilayah ini berbatasan dengan Kecamatan Sukaratu di sebelah utara, Kecamatan Padakembang di timur, Kecamatan 


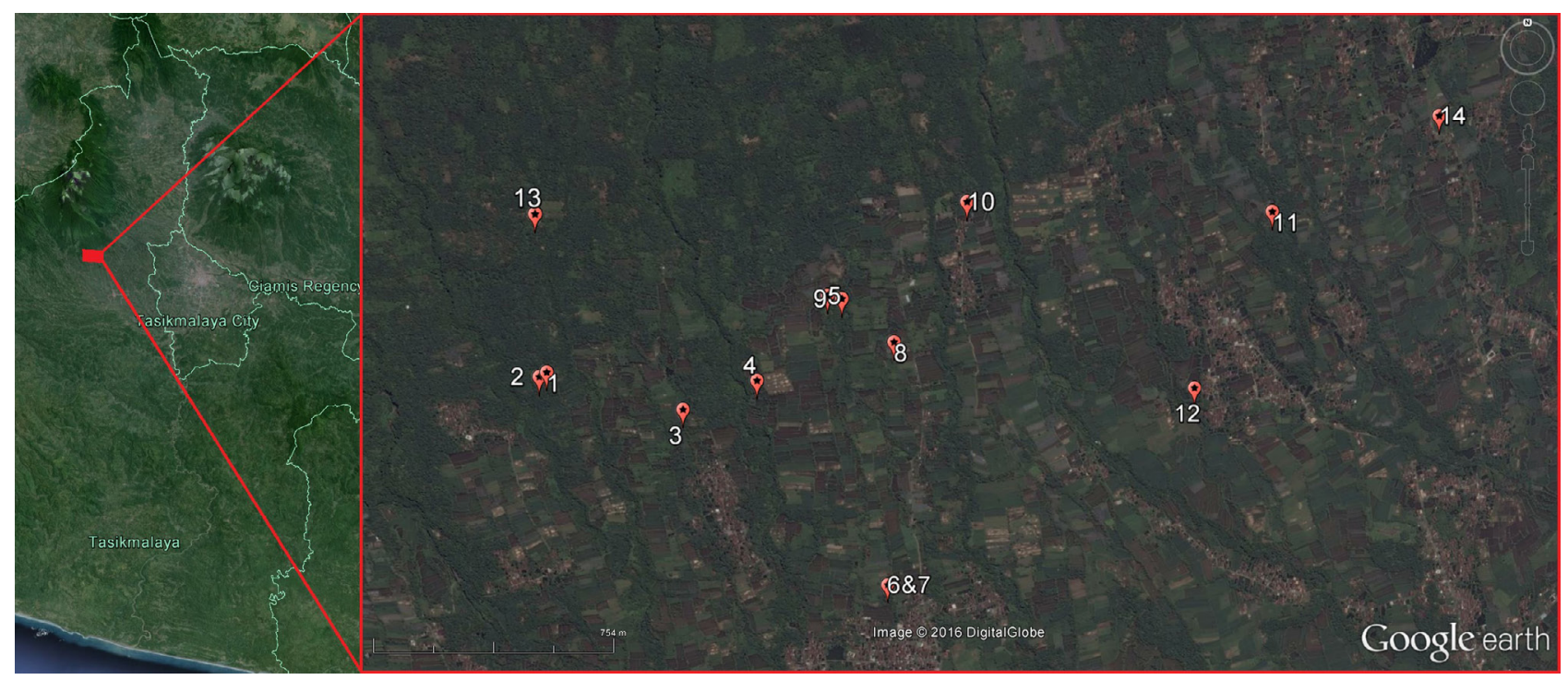

Keterangan gambar:
$\begin{array}{ll} & \text { : Lokasi penelitian wilayah Leuwisari } \\ 1 & \text { : Situs Budak Angon } \\ 2 & \text { : Situs Batu Bonang } \\ 3 & \text { : Situs Candi } \\ 4 & \text { : Situs Ajisaka } \\ 5 & \text { : Situs Talaga Manggung } \\ 6 & \text { : Situs Menhir Sanghyang } \\ 7 & \text { : Situs Saunggaluh }\end{array}$

8 : Situs Batu Pawayangan
9 : Situs Batu Garu
10 : Situs Gegerhanjuang
11 : Situs Kubur Keramat
12 : Situs Sidayang
13 : Situs Menhir Kapolalay
14 : Situs Menhir Cipurut

Gambar 1. Peta persebaran situs-situs di wilayah Leuwisari (Sumber: Diolah dari Google Earth http://www.google.com/earth/)

Singaparna di selatan, dan Kecamatan Sariwangi di barat. Kecamatan Leuwisari terbagi menjadi enam desa, yaitu Desa Arjasari, Desa Ciawang, Desa Linggawangi, Desa Linggamulya, Desa Cigadog, dan Desa Mandalagiri.

Ruang lingkup penelitian budaya megalitik di Leuwisari meliputi 14 situs yang tersebar di empat desa, yaitu Desa Linggawangi, Desa Linggamulya, Desa Cigadog, dan Desa Mandalagiri dengan persebaran situs sebagai berikut. Desa Linggawangi meliputi tiga situs, yaitu Situs Budak Angon, Situs Batu Bonang, dan Situs Candi. Desa Linggamulya meliputi tujuh situs, yaitu Situs Ajisaka, Situs Talaga Manggung, Situs Menhir Sanghyang, Situs Saunggalah, Situs Batu Pawayangan, Situs Batu Garu, dan Situs Gegerhanjuang. Desa Cigadog meliputi tiga situs, yaitu Situs Kubur Keramat, Situs Sidayang, dan Situs Menhir Kapolalay. Desa Mandalagiri hanya terdiri dari satu situs, yaitu Situs Menhir Cipurut (gambar 1).
Pengumpulan data dilakukan dengan pengamatan langsung melalui kegiatan survei dan studi kepustakaan. Studi kepustakaan dilakukan melalui penelusuran terhadap literatur yang berkaitan dengan tinggalantinggalan arkeologi di wilayah Leuwisari. Analisis data dilakukan melalui pendekatan arkeologi ruang dan ekologi dengan mengaitkan pola kelatakan situs dengan kondisi geografis lingkungan. Hasil analisis kemudian disajikan secara deskriptif-kualitatif dan diakhiri dengan kesimpulan.

\section{HASIL DAN PEMBAHASAN}

Pelaksanaan survei di wilayah Leuwisari menunjukkan adanya gejala-gejala budaya material dalam bentuk dan periode tertentu, berupa fitur kubur, punden, batu datar, menhir, fragmen tembikar, serta kerak besi. Hasil identifikasi tersebut diperoleh setelah melalui studi komparasi dengan temuan dari situs-situs 
yangsejenisyangsudahdiketahuiperiodisasinya, seperti di Situs Tugu Gede Sukabumi. Temuan di Leuwisari mempunyai banyak persamaan dengan temuan di situs tersebut, yaitu berasal dari peninggalan budaya megalitik. Tinggalan budaya tersebut merupakan suatu material yang pernah dimanfaatkan untuk aktivitas manusia, baik sebagai sarana untuk memenuhi kebutuhan hidup sehari-hari, permukiman, maupun aktivitas yang berkaitan dengan religi. Data yang berkaitan dengan aktivitas permukiman dan religi ini mencakup situs-situs yang telah ditinggalkan pendukungnya dan situs-situs yang masih digunakan.

Penjaringan data melaui survei di wilayah Leuwisari berhasil menemukan sejumlah situs yang tersebar di empat desa dengan hasil sebagai berikut. Desa Linggawangi memiliki Situs Budak Angon, Situs Batu Bonang, dan Situs Candi. Situs Budak Angon dan Situs Batu Bonang terdiri dari batu tegak atau menhir, punden berupa tumulus Mama Bonang, dan Kolam Cipelak. Kedua situs tersebut berada pada ketinggian sekitar 642-667 meter di atas permukaan laut (mdpl). Sementara itu, Situs Candi memiliki tinggalan arkeologi berupa tatanan batu alam berbentuk segi empat dengan satu batu tegak atau menhir di sisi sebelah utara. Tinggalan arkeologi tersebut mirip dengan punden berteras satu. Situs ini terletak pada ketinggian $621 \mathrm{mdpl}$. Secara keseluruhan, situs-situs di Desa Linggawangi dapat dikelompokkan menjadi situs punden dan petirtaan atau mata air. Tata letak situssitus tersebut berada di lahan yang landai yang terletak di sebelah barat aliran Sungai Cisela yang mengalir dari arah utara ke selatan.

Desa Linggamulya berada di sebelah timur Desa Linggawangi dengan tata letak situs-situsnya berada di lahan yang landai dan tersebar dari arah barat ke timur laut. Sejumlah situs yang terdapat di Desa Linggamulya adalah Situs Ajisaka, Situs Talaga Manggung, Situs Menhir Sanghyang, Situs Saunggalah, Situs Batu Pawayangan, Situs Batu Garu, dan Situs Gegerhanjuang.
Situs Ajisaka terletak pada ketinggian 637 mdpl dan berada di sebelah timur aliran Sungai Cisela dengan jarak sekitar $20 \mathrm{~m}$. Situs Talaga Manggung berada pada ketinggian 642 mdpl, kemudian Situs Menhir Sanghyang berada pada ketinggian $570 \mathrm{mdpl}$, dan di dekat situs tersebut terdapat juga toponimi yang disebut sebagai Situs Saunggalah atau rumah besar. Situs Batu Pawayangan berada pada ketinggian $641 \mathrm{mdpl}$. Situs Batu Garu berada pada ketinggian 645 mdpl dan terletak di sebelah timur laut dari Situs Batu Pawayangan. Situs Batu Garu dikenal juga dengan sebutan Situs Menhir Roboh.

Sebaran situs-situs di Desa Linggamulya kemudian berlanjut ke sebelah timur Sungai Ciampo, yaitu Situs Gegerhanjuang berupa batu datar dan sebaran fragmen gerabah. Situs Gegerhanjuang berada pada ketinggian 667 mdpl. Tata letak situs-situs di Desa Linggamulya berada di antara aliran dua sungai, yaitu Sungai Cisela di sebelah barat dan Sungai Ciampo di sebelah timur. Terdapat juga situs yang terletak di sebelah timur aliran Sungai Ciampo. Situs-situs di Desa Linggamulya dapat dikelompokkan menjadi situs permukiman yang meliputi Situs Ajisaka, Situs Talaga Manggung, Situs Saunggalah, dan Situs Gegerhanjuang. Adapun, situs-situs yang berkaitan dengan aspek religi adalah Situs Sanghyang, Situs Batu Garu, dan Situs Pawayangan.

Desa Cigadog berada di sebelah timur Desa Linggamulya dan memiliki Situs Kubur Keramat, Situs Sidayang, dan Situs Menhir Kapolalay. Situs Kubur Keramat berada pada ketinggian 629 mdpl. Tinggalan arkeologi di Situs Kubur Keramat berupa tatanan batu yang disusun membentuk punden berteras satu, berbentuk segi empat, dan di masing-masing sudutnya berdiri batu tegak atau menhir. Pada bagian tengah di sisi sebelah barat, terdapat menhir yang menghadap ke arah utara, dan batu datar di sebelah timurnya. Menhir di kubur ini memiliki bentuk yang tidak beraturan dan diperkirakan berasal dari batu alam yang digunakan secara langsung. Menhir tersebut berukuran tinggi $50 \mathrm{~cm}$ dan lebar $35 \mathrm{~cm}$. Pada 
sisi timur, terdapat bagian lantai yang diperkeras dengan semen selebar $90 \mathrm{~cm}$ (gambar 2). Tata letak situs ini berada pada bukit yang diapit oleh dua aliran sungai, yaitu Sungai Ciawitali yang mengalir di sebelah barat laut hingga tenggara bukit, kemudian bermuara ke Sungai Ciawang yang mengalir dari arah utara ke selatan. Dua sungai tersebut bertemu di sebelah tenggara Situs Bukit Keramat. Situs ini masih dikeramatkan oleh masyarakat.

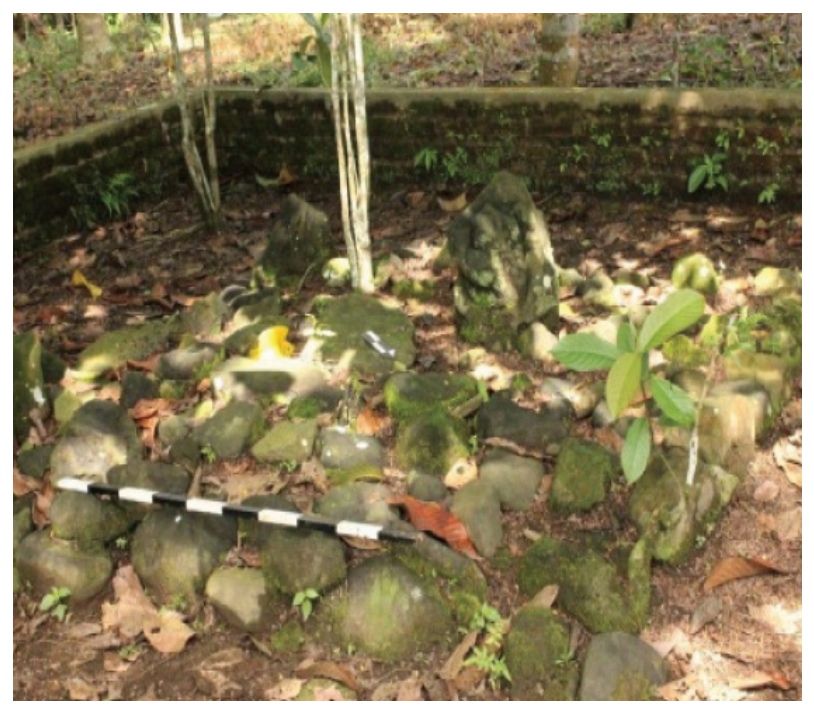

Gambar. 2 Situs Kramat Cigadog di Desa Cigadog, Kec. Leuwisari.

(Sumber: Dokumen Balai Arkeologi Bandung)

Berdasarkan tinggalan arkeologi yang berupa menhir, kubur, dan batu datar, serta lokasi situs yang berada di bukit dan diapit oleh dua sungai, Situs Batu Keramat memberikan gambaran bahwa terdapat konsep budaya megalitik yang pernah berlangsung di situs tersebut. Jika dikaitkan dengan konsep religi prasejarah, penempatan bangunan dalam suatu lokasi yang tinggi berkaitan dengan konsep gunung sebagai tempat abadi para leluhur, dan orientasi kubur yang menganggap arah tertentu sebagai arah sakral (Handini 2003, 24). Menhir di Situs Kubur Keramat menghadap ke arah utara, yaitu ke arah Gunung Galunggung sehingga memberikan gambaran bahwa aktivitas religi yang pernah berlangsung di situs ini berkaitan dengan konsep gunung sebagai tempat suci atau tempat arwah nenek moyang bersemayam. Kondisi ini mengingatkan pada Situs Candi di Linggawangi yang mempunyai fitur tatanan batu segi empat dan menhir di sisi sebelah utara yang menghadap ke Gunung Galunggung.

Situs Sidayang memiliki tinggalan budaya berupa kolam yang saat ini dimanfaatkan sebagai kolam ikan dengan ukuran panjang $40 \mathrm{~m}$ dan lebar $16,5 \mathrm{~m}$. Kolam ini terletak di sebelah timur laut aliran Sungai Cinangka yang merupakan anak Sungai Ciawang, serta berada pada ketinggian 602 mdpl. Pada tepi sisi timur kolam, terdapat artefak lumpang batu dengan diameter lubang $20 \mathrm{~cm}$.

Situs Menhir Kapolalay berada pada ketinggian $638 \mathrm{mdpl}$. Situs ini terletak di sebelah timur laut aliran Sungai Situsaar yang merupakan anak Sungai Cikapas yang bermuara ke Sungai Cimerah di sebelah selatan Desa Cigadog. Menhir di Situs Menhir Kapolalay dipahat dari sebongkah batu dan berbentuk prisma segitiga sama kaki atau berbentuk gunungan. Menhir tersebut memiliki ukuran tinggi penampang $96 \mathrm{~cm}$, lebar sisi dasar 65 $\mathrm{cm}$, panjang sisi miring $100 \mathrm{~cm}$, tebal batu 15 $\mathrm{cm}$. Berdasarkan bentuk pahatannya, menhir ini diperkirakan telah menggunakan perkakas logam sebagai alat pahatnya (gambar 3).

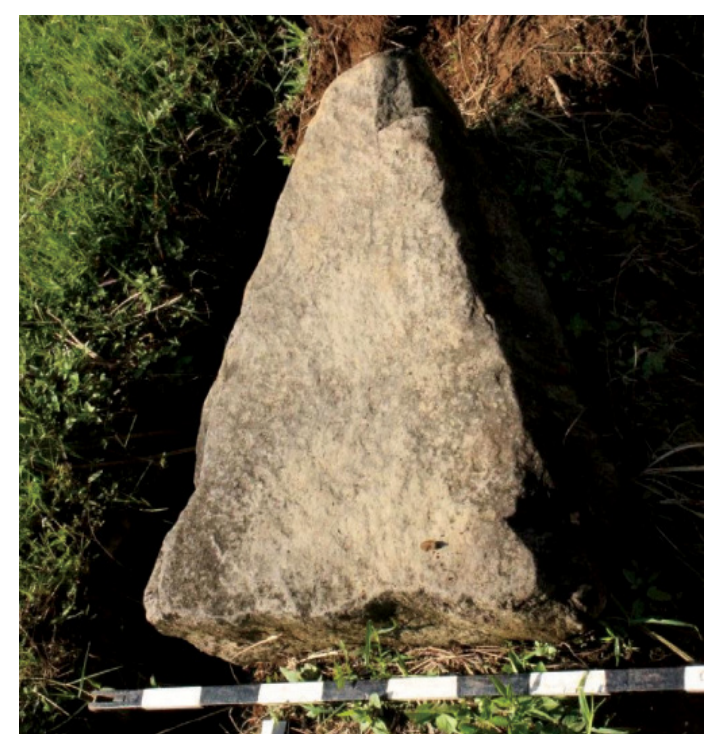

Gambar. 3 Bentuk Menhir Kapolalay (Eyang Gederjaya) di Desa Cigadog

(Sumber: Dokumentasi Balai Arkeologi Bandung) 
Hal ini memberikan gambaran bahwa perkakas dari logam telah digunakan pada masa itu. Penggunaaan logam juga dibuktikan dengan ditemukannya artefak kerak besi pada ekskavasi di kotak uji coba di Situs Gegerhanjuang. Situs-situs di Desa Cigadog umumnya berada di lahan antara aliran Cikapas di sebelah barat dan Ciawang di sebelah timur. Kedua sungai tersebut bermuara ke Sungai Cimerah. Situssitus di Desa Cigadog dapat dikelompokkan menjadi situs permukiman, yaitu Situs Sidayang, serta situs yang terkait dengan aspek religi, yaitu Situs Menhir Kapolalay dan Situs Kubur Keramat.

Desa Mandalagiri yang terletak di sebelah timur Sungai Ciawang hanya memiliki satu situs, yaitu Situs Menhir Cipurut atau dikenal juga dengan nama Tugu Cipurut. Menhir ini sudah longsor dari palinggih-nya. Menhir ini memiliki bentuk penampang segi empat dengan lebar kaki yang lebih pendek daripada lebar puncaknya. Menhir Cipurut memiliki tinggi $140 \mathrm{~cm}$, lebar kaki $10 \mathrm{~cm}$, lebar puncak $50 \mathrm{~cm}$, lebar bagian tengah $46 \mathrm{~cm}$, dan tebal $29 \mathrm{~cm}$. Menhir ini sekarang berada di sawah, sedangkan pondasi menhir atau palinggih-nya yang berupa tiga buah batu masih terletak di tempatnya. Menhir ini berada pada ketinggian 631 mdpl. Berdasarkan tinggalan budayanya, religi yang pernah berkembang di wilayah ini diduga berupa pemujaan terhadap roh nenek moyang dan menganggap gunung sebagai tempat yang suci atau sakral. Konsep kepercayaan budaya megalitik melahirkan tradisi mendirikan bangunan-bangunan monumental yang terbuat dari batu sebagai tempat kegiatan ritual atau pemujaan terhadap roh nenek moyang. Masyarakat pendukung budaya megalitik juga percaya bahwa gunung adalah tempat yang suci (Sulistyarto 2003, 15-23). Berdasarkan jenisnya, situs-situs yang terkait dengan budaya megalitik di wilayah Leuwisari dapat ditunjukkan dalam tabel 1.

Keterkaitan antara situs dengan bentang alam lereng selatan Gunung Galunggung dibahas dengan menggunakan pendekatan arkeologi ruang. Arkeologi ruang merupakan salah satu studi khusus dalam ilmu arkeologi dengan memusatkan perhatian pada pengkajian dimensi ruang daripada pengkajian dimensi bentuk atau formal dan waktu atau temporal. Ruang dapat berarti suatu wilayah yang di dalamnya tersebar situs-situs arkeologi, kemudian mencari hubungan antara benda dengan benda, situs dengan situs, dan benda atau situs dengan lingkungan fisiknya sebagai sumber daya (Mundardjito 1995, 25). Dimensi ruang merupakan keseluruhan lingkungan

Tabel 1. Jenis-jenis situs megalitik yang terdapat di wilayah Leuwisari

\begin{tabular}{|c|c|c|c|}
\hline Lokasi & Situs & Religi & Permukiman \\
\hline \multirow[t]{3}{*}{ Desa Linggawangi } & Situs Budak Angon & $\sqrt{ }$ & \\
\hline & Situs Batu Bonang & $\sqrt{ }$ & \\
\hline & Situs Candi & $\sqrt{ }$ & \\
\hline \multirow[t]{7}{*}{ Desa Linggamulya } & Situs Ajisaka & & $\sqrt{ }$ \\
\hline & Situs Talaga Manggung & & $\sqrt{ }$ \\
\hline & Situs Menhir Sanghyang & $\sqrt{ }$ & \\
\hline & Situs Saunggalah & & $\sqrt{ }$ \\
\hline & Situs Batu Pawayangan & $\sqrt{ }$ & \\
\hline & Situs Batu Garu & $\sqrt{ }$ & \\
\hline & Situs Gegerhanjuang & & $\sqrt{ }$ \\
\hline \multirow[t]{3}{*}{ Desa Cigadog } & Situs Kubur Keramat & $\sqrt{ }$ & \\
\hline & Situs Sidayang & & $\sqrt{ }$ \\
\hline & Situs Menhir Kapolalay & $\sqrt{ }$ & \\
\hline Desa Mandalagiri & Situs Menhir Cipurut & $\sqrt{ }$ & \\
\hline
\end{tabular}

(Sumber: Dokumen pribadi) 
hidup sebagai ruang yang bisa dihayati dan dapat dimanfaatkan untuk memenuhi kebutuhan tertentu (Aziz 1995, 43). Dalam hal ini, ruang mempunyai batasan geografis dan batas yang dimaksud dapat berupa batas alam, seperti sungai, hutan, dan bukit yang melingkupi sebaran budaya yang ada. Ruang juga dapat berarti sebagai tempat manusia berkumpul dan hidup bersama dengan memanfaatkan sumber daya lingkungan alam dalam mempertahankan kelangsungan hidupnya. Pendapat tersebut sejalan dengan pendapat Subroto $(1995,133)$ yang menyatakan bahwa persebaran situs-situs akan menghasilkan pola-pola tertentu yang berhubungan dengan strategi subsistensi. Dalam hal ini, lingkungan dengan kategori sumber daya tertentu menjadi pilihan yang menentukan. Iklim merupakan salah satu faktor penting yang mempengaruhi distribusi semua mahluk hidup di muka bumi karena iklim menentukan tingkat kehangatan, kelembaban, dan semua sumber bahan baku yang diperlukan mahluk hidup (Subroto 1995, 133). Oleh karena itu, bentang lahan, keberadaan flora dan fauna juga merupakan pilihan yang dipertimbangkan untuk menentukan lokasi situs, serta kemampuan teknologi yang dikuasainya. Manusia dituntut untuk menyesuaikan diri dengan kondisi lingkungan yang ada. Melalui pengkajian tinggalan arkeologis dan dikaitkan dengan analisis mengenai lingkungan, pembahasan dapat menggambarkan pola penempatan situssitus di wilayah Leuwisari.

Bentang lahan wilayah Tasikmalaya, khususnya Leuwisari, umumnya termasuk ke dalam zona pegunungan selatan Jawa Barat yang memanjang dari Teluk Ciletuh di Banten sampai Pulau Nusakambangan. Wilayah Leuwisari terbentang di lereng selatan Gunung Galunggung dengan ketinggian antara 570-667 mdpl. Wilayah ini beriklim tropis dengan curah hujan sekitar $2.072 \mathrm{~mm} /$ tahun, suhu udara berkisar antara $18-22^{\circ} \mathrm{C}$ di dataran tinggi, dan $20-34^{\circ} \mathrm{C}$ di dataran rendah (id.wikipedia.org/ wiki/kabupaten tasikmalaya).
Berdasarkan peta fisiografi JawaMadura R. W. van Bemmelen (dalam Agus 2005, 4), wilayah ini termasuk ke dalam zona pegunungan selatan Jawa Barat. Batuan yang menyusun bentang alam ini berupa breksi vulkanik dengan bongkah lava andesit yang dihasilkan pada tingkat gunung api tua. Adapun pada tingkat gunung api muda, susunan batuan mulai dari breksi gunung api, lahar, tufa berlapis, batuan andesit, hingga basal. Kenampakan satuan geomorfologi Tasikmalaya terdiri dari satuan morfologi bergelombang sedang sampai kuat, dengan kisaran ketinggian antara 200$600 \mathrm{mdpl}$. Satuan geomorfologi Tasikmalaya terbagi dalam satuan geomorfologi perbukitan landai pada bagian barat laut dengan ketinggian 280-475 mdpl, perbukitan soliter dengan ukuran bervariasi berkisar puluhan meter, dan pedataran pada bagian tengah dan timur dengan ketinggian 201-350 mdpl. Sementara itu, kemiringan lahan umumnya landai dengan kisaran 2\%-5\% dan curam dengan kisaran 5\%$15 \%$. Hasil pengamatan di lapangan umumnya menunjukkan lahan perbukitan landai hingga curam (http://www.tasikmalayakota.go.id). Pada wilayah barat laut berupa pegunungan Galunggung, ketinggian bervariasi antara 200500 mdpl hingga ketinggian 2.168 mdpl yang merupakan puncak Galunggung.

Sumber daya air berupa sungai di wilayah ini di antaranya adalah Sungai Cimerah, Cisela, Ciampo, Cikapas, Ciawang yang bermuara ke Cimerah, dan anak Sungai Cinangka, Ciawitali, serta Sungai Situsaar yang bermuara ke Ciawang yang selanjutnya bermuara juga ke Sungai Cimerah. Sumber daya air di wilayah ini berasal dari air permukaan dan air hujan, sementara air tanah berada pada kedalaman sumur antara 3-10 m. Air permukaan dan air hujan umumnya akan mengisi aliran sungaisungai tersebut di atas. Selain menyimpan air sungai, wilayah ini umumnya banyak menyimpan batuan yang dapat dimanfaatkan untuk kegiatan budaya. Pengamatan terhadap jenis batuan yang digunakan untuk bahan 
material budaya umumnya berjenis batuan andesit. Batuan tersebut menyerupai jenis batuan yang terdapat di sungai-sungai wilayah penelitian sehingga diperkirakan sumber batuan diambil dari sungai tersebut. Sungai-sungai di lokasi penelitian ini umumnya mengalir dari arah utara ke selatan, mengikuti topografi lahan yang melandai ke selatan sehingga memberikan aliran sungai berpola radial. Pola radial adalah pola penyaluran melingkar yang dibentuk oleh aliran sungai yang keluar dari daerah yang tinggi. Pola ini adalah pola khas pada daerah gunung api, kubah, dan pada tubuh intrusi batuan beku vulkanik (Eriawati 2004, 48-61).

Pembahasan mengacu kepada pengertian tentang lahan, mencakup lingkungan fisik yang terdiri atas iklim, relief, tanah, air, vegetasi dan benda-benda lain di atasnya, sepanjang memiliki pengaruh terhadap penggunaan lahan, termasuk hasil kegiatan manusia di masa silam dan sekarang (Sudiono 2004, 126-145). Lahan atau tanah di daerah aliran sungai ini merupakan dataran aluvial yang bercampur dengan abu vulkanik dan tuva lapukan sehingga merupakan lahan yang potensial sebagai tempat berbagai jenis vegetasi. Wilayah ini termasuk dalam wilayah hutan hujan tropis sehingga tumbuh berbagai vegetasi. Beberapa jenis dari tumbuhan tropis tersebut dapat dipastikan sebagai tanaman yang bisa dikonsumsi untuk memenuhi kebutuhan hidup manusia. Oleh karena itu, kebutuhan hidup sehari-hari masyarakat pendukung budaya megalitik yang berupa makanan berasal dari lingkungan alam sekitarnya. Kondisi lahan seperti ini berlanjut hingga ke sebelah selatan kawasan situs sehingga menjadi daya tarik manusia untuk memilih dan menempatinya serta diperkirakan telah berlangsung sejak masa lampau.

Sebaran situs-situs di wilayah Leuwisari menunjukkan bahwa situs-situs di lereng selatan Gunung Galunggung menempati ketinggian lahan tertentu. Dalam wilayah Leuwisari, situs dengan keletakan terendah adalah Situs Menhir Sanghyang, sedangkan situs dengan keletakan tertinggi adalah Situs Gegerhanjuang.
Secara keseluruhan, situs-situs yang berkaitan dengan aspek permukiman di wilayah Leuwisari, khususnya di Desa Linggamulya, menempati lahan yang lebih lebih tinggi dibandingkan dengan situs yang berkaitan dengan aspek religi. Kondisi tersebut diperkirakan berkaitan dengan kondisi lahan. Lahan di sekitar Situs Menhir Sanghyang umumnya lebih landai dan lebih luas jika dibandingkan dengan lahan tempat permukiman yang kondisinya lebih curam.

Pertimbangan lain ialah menhir atau megalit merupakan pusat upacara yang digunakan sebagai penghubung antara alam manusia dan alam supranatural sehingga sering dikunjungi oleh pendukungnya dan memerlukan lahan yang mudah untuk diakses serta luas. Situs ini berjarak sekitar 50-100 m dari aliran Sungai Ciampo yang diperkirakan pernah digunakan sebagai sarana jalan pada masa lampau.

Keletakan situs-situs dengan sumber daya sungai menunjukkan adanya keterkaitan distribusi situs dengan bentang lahan, yaitu tampak bahwa penempatan situs-situs di Desa Linggawangi berada di sebelah barat aliran Sungai Cisela, dan situs-situs di Desa Linggamulya berada di antara aliran Sungai Cisela dan Ciampo, sedangkan situs-situs di Desa Cigadog berada di antara aliran Sungai Cikapas dan Ciawang.

Masyarakat pendukung budaya megalitik di Leuwisari menempati zona-zona subur di daerah sekitar aliran sungai. Hal ini menimbulkan dugaan bahwa pendukung budaya megalitik di wilayah ini beradaptasi dengan kondisi lingkungannya. Masyarakat pendukung budaya megalitik umumnya hidup dengan bercocok tanam di lahan pertanian sehingga akan memilih tempat yang subur.

Berdasarkan sudut pandang deterministik, hubungan antara lingkungan dan manusia didefinisikan bahwa segala aspek kebudayaan dan tingkah laku manusia disebabkan secara langsung oleh pengaruh lingkungan. Interaksi antara manusia dan lingkungan alamnya dapat 
terwujud dalam bentuk kegiatan manusia dalam memenuhi kebutuhan hidupnya, seperti mengambil materi yang ada di lingkungan hidupnya, baik di sungai maupun di darat, untuk kebutuhan yang bersifat religius atau non religius (Sukendar 1991, 73; Prijono 2014, 11). Dalam konteks budaya megalitik di wilayah Leuwisari, keterkaitan antara manusia dengan lingkungan alamnya ditunjukkan melalui tata letak situs yang berada di daerah aliran sungai karena pada umumnya tanah di sekitar aliran sungai subur sehingga mudah untuk dilakukan kegiatan bercocok tanam. Selain itu, sungai menyimpan batuan yang dapat digunakan sebagai bahan media pemujaan. Sungai dapat juga dimanfaatkan untuk keperluan ekonomi karena merupakan tempat hidupnya ikan, dan dapat dimanfaatkan sebagai batas alam dalam pertahanan wilayahnya.

\section{KESIMPULAN}

Persebaran tinggalan budaya megalitik di wilayah Leuwisari tersebar di empat desa, dan sebagian besar situs-situs menempati lahan di antara aliran dua sungai, yaitu di sekitar aliran Sungai Cisela dan Sungai Ciampo, dan di antara aliran Sungai Cikapas dan Sungai Ciawang. Masyarakat pendukung budaya megalitik di wilayah Leuwisari memilih dan memanfaatkan sumber daya alam, khususnya sungai, sebagai sarana jalan, sarana ekonomi, dan pertahanan wilayah dari serangan musuh. Aktivitas tersebut menghasilkan tata letak situs yang mengikuti aliran sungai dari arah utara ke selatan sehingga membentuk pola penempatan situs yang linear. Wilayah Leuwisari, khususnya lereng Gunung Galunggung sebelah selatan, merupakan kawasan yang pernah dihuni oleh masyarakat budaya megalitik yang mata pencaharian hidupnya melalui kegiatan bercocok tanam. Masyarakat pendukung budaya megalitik di wilayah Leuwisari menganut kepercayaan terhadap roh nenek moyang, dan memuja gunung sebagai tempat yang suci, serta memiliki tradisi mendirikan bangunanbangunan megalitik sebagai sarana pemujaan.

\section{DAFTAR PUSTAKA}

Agus. 2005. "Ragam Aktivitas di Gua Nangsi." Laporan Hasil Penelitian Arkeologi, Balai Arkeologi Bandung, Bandung.

Aziz, Fadhilla Arifin.1995. "Situs Gilimanuk (Bali) Sebagai Pilihan Lokasi Penguburan Pada Awal Masehi." Berkala Arkeologi XV:43-46.

Eriawati, Yusmaini. 2004. "Distribusi Tinggalan Megalitik di Jember, Jawa Timur Kaitannya Dengan Ketersediaan Batuan.” Dalam Lingkungan Masa Lampau Beberapa Situs Arkeologi di Jawa Timur dan Bali, 4861. Jakarta: Kementerian Kebudayaan dan Pariwisata.

Handini, Retno. 2003. "Pertanggalan Absolut Situs Kubur Kalang: Signifikasinya bagi Periodisasi Kubur Peti Batu di Daerah Bojonegoro dan Tuban, Jawa Timur." Berkala Arkeologi XXIII:24-38.

Mundarjito. 1995. "Kajian Kawasan: pendekatan Setrategis Dalam Penelitian Arkeologi di Indonesia Dewasa ini." Berkala Arkeologi $\mathrm{XV}: 25-28$.

Prijono, Sudarti. 2014. "Aspek-Aspek Arkeologis Pada Situs-Situs Bercorak Megalitik di Kawasan Bantarkalong Tasikmalaya." Purbawidya 3 (1): 1-16.

Siregar, Sondang. M. 2010. "Pola Sebaran SitusSitus Arkeologi Di Kaasan Danau Ranau." Siddhayatra 15 (2): 19-26.

Subroto, Ph. 1995. "Pola-Pola Zonal Situs-Situs Arkeologi." Berkala Arkeologi XV:133-143.

Sudiono. 2004. "Aspek Lingkungan Alam Yang Menunjang Kelangsungan Budaya Perundagian di Pesisir Pantai Tejakula, Bali." Dalam Lingkungan Masa Lampau Beberapa Situs Arkeologi di Jawa Timur dan Bali, 126145. Jakarta: Kementerian Kebudayaan dan Pariwisata.

Sukendar, Haris. 1991. "Mata Pencaharian, Kemahiran Teknologi dan Sumber Daya Alam Dalam Hubungannya Dengan Eksistensi Megalitik di Dataran Tinggi Pasemah." Dalam Proceedings Analisis Hasil Penelitian Arkeologi II, 65-78. Jakarta: Departemen Pendidikan dan Kebudayaan.

Sulistyarto, Priyatno Hadi. 2003. "Hindunisasi di Kawasan Megalitik Gunung Slamet." Berkala Arkeologi XXIII:15-23. 
http://www.tasikmalayakota.go.id. "Gambaran Umum Kondisi Wilayah Tasikmalaya," diakses 24 Februari 2015.
Wikipedia. 2015. "Kabupaten Tasikmalaya." https://id.wikipedia.org/wiki/Kabupaten Tasikmalaya, diakses 24 Februari 2015. 